\title{
Entangled Legalities beyond the (Byzantine) State
}

Towards a User Theory of Jurisdiction

\author{
CAROLINE HUMFRESS
}

\subsection{Introduction}

At the outset, I ask the historian to look upon Indian America as a Middle Ages which was missing its Rome: a confused mass that emerged from an ancient syncretism, which was without doubt very loosely textured, that had contained within itself at one and the same time, for many centuries, centres of advanced civilisation and savage peoples, centralizing tendencies and disruptive forces. ${ }^{1}$

In 1964, the French social anthropologist and exponent of structuralism, Claude Lévi-Strauss, published volume one of his celebrated series Mythologiques: Le Cru et le Cuit, translated into English in 1969 as The Raw and the Cooked. In the volume's introductory chapter, Lévi-Strauss offered an explanation of the group nature of the Amerindian myths analysed in the volume. With his arresting image of Indian America before the ages of European conquest as 'a Middle Ages which was missing its Rome', Lévi-Strauss invoked a - seemingly eternal - idea of 'Rome' as a source of order and normativity. For Lévi-Strauss, the structure of Amerindian mythologies differed from those of medieval Europe because there was no 'Rome' - neither empire nor Church - to act as a centralizing, structuring, unifying force. Nonetheless, as Lévi-Strauss' Mythologiques set out to prove, there was structure to the

${ }^{1}$ C. Lévi-Strauss, Mythologiques: Le Cru et le Cuit (Plon, 1964), p. 16 (own translation): 'On commencera donc par inviter l'historien à voir, dans l'Amérique indienne, un Moyen âge auquel aurait manqué sa Rome: masse confuse, elle-même issue d'un vieux synrétisme dont la texture fut sans doute très lâche, et au sein de lacquelle subsistèrent çà et là, pendant plusiers siècles, des foyers de haute civilisation et des peuples barbares, des tendances centralisatrices et des forces de morcellement.' 
seemingly 'confused mass' of Amerindian myth. ${ }^{2}$ I begin with LéviStrauss and his vision of 'a Middle Ages which was missing its Rome' in order to problematize the idea of centralized authority itself. More specifically, this chapter challenges the seemingly natural idea, typified here by Lévi-Strauss, that the presence of a Rome - or a Brussels, or a United Nations, or even a UNIDROIT - implies the development of a centralized, hierarchical model through which various, heteronomous, normative orders politely interact.

'Rome' here performs as shorthand for the deceptively complex idea that law and governance should be understood primarily in the context of imperium: the power to command. As Karen Alter states: 'Most people presume that law is only meaningful when backed by a central enforcer.' Hence for much of the twentieth century, in the absence of a 'world state', international relations could be conceptualized as operating outside the domain of law. Since 1989 the number of international courts has more than quadrupled in number from six to over twenty-four - resulting in the collective issuing of over 37,000 binding legal rulings in individual contentious cases. ${ }^{4}$ Yet even this intensified judicialization of the international arena still tends to be framed by a persistent image of law beyond the nation state as a weak ordering and regulatory system, rather than a constitutive element in the ongoing tumble of transnational life. ${ }^{5}$ The field of private international law - 'the legal discipline that determines in which cases a court must apply a foreign law' - also rests on a paradigm of Westphalian state governance. ${ }^{6}$ Private international law 'does not lay out substantive rules for such situations, but merely resolves

2 Ibid., p. 11: 'Des filaments épars se soudent, des lacunes se comblent, des connexions s'établissent, quelque chose qui ressemble à un ordre transparait derrière le chaos. Comme autour d'une molécule germinale, des séquences rangées en groupes de transformations viennent s'agréger au groupe intial, reproduisant sa structure et ses déterminations. Un corps multi-dimensionnel nâit, dont les parties centrales dévoilent l'organisation alors que l'incercitude et la confusion règnent encore au portour.'

${ }^{3}$ K. J. Alter, The New Terrain of International Law: Courts, Politics, Rights (Princeton University Press, 2014), p. 3.

${ }^{4}$ Ibid., p. 3.

5 D. Kennedy, 'Law in Global Political Economy: Now You See It, Now You Don't', in P. F. Kjaer (ed.), The Law of Political Economy: Transformation in the Function of Law (Cambridge University Press, 2020), pp. 127-51, at p. 128.

${ }^{6}$ Quotation from R. Michaels, 'What Is Non-state Law? A Primer', in M. A. Helfand (ed.), Negotiating State and Non-state Law: The Challenge of Global and Local Legal Pluralism (Cambridge University Press, 2015), pp. 41-58, at p. 55. On 'the peace of Westphalia' (1648) and the emergence of the modern state as 'an international subject' see A. Cassese, 'States: Rise and Decline of the Primary Subjects of the International Community', in 
conflicts between the legal orders themselves', relying on relevant domestic choice-of-law principles and rules in order to resolve legal disputes with a foreign element. ${ }^{7}$ As Neil Walker notes, choice-of-law rules 'and the interpretative aids of transnational law do not "stand above" the domestic systems in which they are applied. Rather, they are formulated or interpreted each in the context of their own system - in deference to and under the self-validating terms prescribed by each domestic legal order's sovereign authority.8 Notwithstanding the 'equality' between different domestic legal orders, the system of private international law prioritizes national sovereignty and is grounded within a hierarchical - in a Kelsenian sense - approach to international governance.

In contrast, the 'postnational' approach, as defined by Nico Krisch in his 2010 Beyond Constitutionalism: The Pluralist Structure of Postnational Law and further developed by the 'Entangled Legalities' project underlying this volume, argues that 'national' and 'international' law are interwoven to such an extent within the supranational legal order that norms and principles from both spheres interact heterarchically: 'operating side-by-side without the presumptive authority of one over the other.' ${ }^{9}$ Like Lévi-Strauss' pre-conquest Amerindian myths, there is no centre or hierarchy (no 'Rome') to structure postnational law. Nonetheless, again like Lévi-Strauss' account of Amerindian mythmaking, there is a structure at work: 'the nation-state itself shares ultimate authority with multiple regional and international legal orders with which it interacts without a common normative framework - hence a post-national law within a pluralist structure. ${ }^{10}$ Instead of mapping the contours of an emerging global constitutional framework in which

B. Fassbender and A. Peters (eds), The Oxford Handbook of the History of International Law (Oxford University Press, 2012), pp. 49-69.

7 R. Michaels, 'A Symmetry of Asymmetries? A Private-International-Law Reconstruction of Lindahl's Work on Boundaries' (2019) 29 Duke Journal of Comparative and International Law 405-22, at 410.

${ }^{8}$ N. Walker, 'Beyond Boundary Disputes and Basic Grids: Mapping the Global Disorder of Normative Orders' (2008) 6 (3-4) International Journal of Constitutional Law 373-96, at 377.

9 C. Mac Amlaigh, 'Pluralising Constitutional Pluralism', in N. Roughan and A. Halpin (eds), In Pursuit of Pluralist Jurisprudence (Cambridge University Press, 2017), pp. 64-89, at p. 68.

${ }^{10}$ G. Shaffer, 'A Transnational Take on Krisch's Pluralist Postnational Law' (2012) 23 The European Journal of International Law 565-82, at 566 (review of N. Krisch, Beyond Constitutionalism: The Pluralist Structure of Postnational Law (Oxford University Press, 2010)). 
overarching principles govern relations between different normative orders, this volume's project seeks to reimagine the global legal order 'through the paradigm of entangled legalities':

In short, we advance a view of global legal order that dissociates itself from the idea of law as a hierarchical system. In its place, we envision global law as having a fluid, network-like structure [...] the Interface Law Project proposes the concept of interface norms that structure fluid and shifting relations between different bodies of norms. Interface law (or law at the interfaces) allows us to isolate and describe the form and substance of these interactions through which the global legal order is being negotiated, constructed and contested, as well as enabling us to catch glimpses of the social practices shaping these processes. ${ }^{11}$

We shall return to the idea of interface norms structuring 'fluid and shifting relations between different bodies of norms' in greater detail in Section 13.2. For the moment, we should simply note that the 'postnational space seems to demand new, different, answers to the question of how to structure governance.' ${ }^{12}$

Rafael Domingo has recently argued, in the context of 'global constitutionalism', that if the future of the supranational legal order is postsovereigntist, postnationalist and postpositivist, 'Roman law was, so to speak, pre all of them: presovereigntist, prenationalist, and prepositivist'. ${ }^{13}$ Most legal historians would agree, however, that there was something akin to 'international law' in Greco-Roman antiquity (and in earlier antiquity too): a rule of law that governed relations between states, alongside the use of brute force. ${ }^{14}$ Historians of Greco-Roman international law' tend to focus predominately on the laws of war and

${ }^{11}$ L. L. Reimers and F. Corradini, 'The Entanglement of Global Legal Order', The Global (9 July 2018), https://theglobal.blog/2018/07/09/the-entanglement-of-global-legal-order/.

12 Krisch, Beyond Constitutionalism, 69.

13 R. Domingo, 'Roman Law and Global Constitutionalism' (2019) 21 San Diego International Law Journal 217-40, at 218. See also T. Duve, 'Entanglements in Legal History. Introductory Remarks', in T. Duve (ed.), Entanglements in Legal History: Conceptual Approaches (Max Planck Institute for European Legal History, 2014), pp. 3-25, at p. 3: 'In large part, legal historical research is dedicated to times and spaces in which the notion of the "modern state" did not exist, or to historical situations of limited statehood.'

14 D. J. Bederman, International Law in Antiquity (Cambridge University Press, 2001). For further discussion see R. Lesaffer, 'Roman Law and the Early Historiography of International Law: Ward, Wheaton, Hosack and Walker', in T. Marauhn and H. Steiger (eds), Universality and Continuity in International Law (Eleven International Publishing, 2011), pp. 149-84, at pp. 149-52. 
diplomacy, including interstate peace treaties. Beyond the political and economic ordering of interstate relations, guaranteed by mutual oathtaking and divine invocation, Greco-Roman peace treaties also included clauses providing for the resolution of on-the-ground disputes that might otherwise threaten the newly agreed order. For example, the treaty concluded in 562 CE between the (Eastern) Roman Emperor Justinian I and the Sasanian King of Kings Xusro I set out - in both Greek and Persian languages - the terms of a fifty-year peace agreed between Rome and Sasanian Iran. ${ }^{15}$ This $562 \mathrm{CE}$ treaty contains two articles that could be compared loosely with modern 'private international law' provisions. Article 7 specifies that individuals who 'have suffered some hurt at the hands of subjects of the other state' should settle the dispute according to law: 'either those who have suffered harm themselves, or their representatives, shall meet on the frontier before the officials of both states, and in this manner the aggressor shall make amends for the damage. ${ }^{16}$ Article 11 , on the other hand, specifies the procedure to be followed in the case of intercity disputes that fall outside the 'rules of war':

If one city damages another or in any way destroys its property not in accordance with the rules of war and with a regular military force, but by guile and theft (for there are such godless men who do these things so that there might be a pretext for war), it was agreed that the judges stationed on the frontiers of both states should make a thorough investigation of such acts and remedy them. ${ }^{17}$

There follow various provisions outlining what should happen if the judges from the frontier zone are unable to resolve a dispute, culminating in a referral to the relevant ruler and a one-year delay before the peace treaty is held to have been broken. The fact that the provisions of the 562 $\mathrm{CE}$ treaty itself were negotiated and concluded on the frontier between the Roman and Sasanian Empires, at the border city of Dara, is a further reminder of what the plural constitutionalist theorist Neil Walker terms the 'centrality of the margins'. ${ }^{18}$ Articles 7 and 11 of the 562 CE treatise, moreover, provide concrete examples of how action at the margins can

15 The Greek text is included in a sixth-century CE history written by 'Menander Protector', Fragment 6.1. 314-97. English translation from G. Greatrex and S. Lieu, The Roman Eastern Frontier and the Persian Wars: Part II AD 363-630 (Routledge, 2002), pp. 132-3 (revised Menander Protector, The History of Menander Protector, ed. and trans. R. Blockley (F. Cairns, 1985).

16 Greatrex and Lieu, The Roman Eastern Frontier, p. 133 (my emphasis).

17 Ibid., p. 133.

18 Walker, 'Beyond Boundary Disputes and Basic Grids', 376-85 and 394-5. 
be seen to structure an overall order. We shall return to this idea of the 'centrality of the margins' in Sections 13.2 and 13.3.

Whether there is anything in Classical or Postclassical Roman legal sources that could be mapped accurately onto the modern concept of 'private international law' is doubtful at best. ${ }^{19}$ In fact, as we shall see in Section 13.3, the coordination of legal sources within the Roman Empire has more in common with the heterarchical approach of 'postnational law' than with the state sovereignty model of private international law. As Ulrike Babusiaux argues in a 2020 article comparing the legal ordering of imperial Rome with the legal ordering of the European Union, the question of 'how to coordinate different legal sources without abstract hierarchy' is an ancient one. ${ }^{20}$ During the late Roman Republic, practical and concrete jurisdictional questions arose in the context of Roman imperial expansion and the creation of the provincial system. ${ }^{21}$ Contact between Roman citizens and 'foreigners' (peregrini, free citizens of any political community besides the Roman) was unavoidable, especially in relation to commerce and business dealings more generally. ${ }^{22}$ Roman magistrates, legal experts (iurisperiti), the emperors and their officials were thus well aware of a world of private legal transactions involving 'non-citizens' of various different types and recognized the need to regulate those transactions from within the Roman legal system. At Rome, from at least the time of the first Emperor Augustus, the praetor peregrinus handled litigation between 'foreigners' and also cases between 'foreigners' and Roman citizens. ${ }^{23}$ The activity of the praetor peregrinus (and the praetor urbanus) at Rome may, to some extent, explain the origins of the Roman ius gentium: 'those legal habits which were accepted

19 For further discussion see H. Cotton, 'Private International Law or Conflicts of Laws: Reflections on Roman Provincial Jurisdiction', in R. Haensch and J. Heinrichs (eds), Herrschen und Verwalten. Der Alltag der römischen Administration in der Hohen Kaiserzeit (Böhlau, 2007), pp. 235-55.

${ }^{20}$ U. Babusiaux, 'Coordination of Different Layers of Law in the Roman Empire and in the European Union', in U. Babusiaux and M. Igimi, Messages from Antiquity: Roman Law and Current Legal Debates (Böhlau Publishers, 2020), pp. 131-67, at p. 131 (my emphasis).

${ }^{21}$ Famous examples include Cicero's discussion of Roman jurisdiction in Sicily, 70 BCE (Against Verres II, 2.32) and the Cyrene edicts of the Emperor Augustus, 7-4 BCE. See further J. Richardson, 'Roman Law in the Provinces', in D. Johnston (ed.), The Cambridge Companion to Roman Law (Cambridge University Press, 2015), pp. 45-58.

${ }^{22}$ G. Minaud, Les gens du commerce et le droit à Rome: Essai d'histoire juridique et social du commerce dans le monde antique romain (Presses universitaires d'Aix-Marseille, 2011).

${ }^{23}$ D. Daube, 'The Peregrine Praetor' (1951) 41 The Journal of Roman Studies 66-70. 
by the Roman law as applying to, and being used by, all the people they met, whether Roman citizens or not. ${ }^{24}$ The elaboration of this concept enabled Roman jurists to define certain private law interactions between peregrini, 'Latins' (who had some of the rights and privileges of Roman citizenship via Roman grants of the ius Latii) and Roman citizens, as falling under Roman jurisdiction. For example, peregrini could acquire ownership through 'natural' modes of acquisition (traditio, occupatio, accessio) and certain contracts of buying, selling and letting were also understood to be part of the ius gentium; slavery was iure gentium, all peoples had it although there were aspects of the (Roman) law of slavery that were peculiar to the Roman ius civile alone; and in certain Roman law actions a legal fiction even enabled foreigners to sue or be sued 'as if they were Roman citizens. ${ }^{25}$ The important point to note here is that while Roman jurists and magistrates worked within a conceptual framework that acknowledged different 'layers of law' (Rechtsschichten), including the ius gentium, their start and end point was the resolution of cases - hypothetical and real - in accordance with the citizen-law of Rome itself. $^{26}$ The opening of Gaius' Institutes, a mid-second-century CE introduction to Roman law, famously refers to 'all peoples who are governed by laws and customs' as having their own bodies of citizenlaw - yet there are no extended discussions of clashes between national laws, nor 'cases [in which] a court must apply a foreign law', in Classical Roman juristic texts. ${ }^{27}$ There is, however, an explicit discourse in both extra-legal and legal Roman texts acknowledging 'overlapping spheres' and entangled norms within Roman private law. ${ }^{28}$

24 J. Crook, Law and Life in Ancient Rome (Cornell University Press, 1967), p. 29.

${ }^{25}$ C. Humfress, 'Law's Empire: Roman Universalism and Legal Practice', in P. du Plessis (ed.), New Frontiers: Law and Society in the Roman World (Edinburgh University Press, 2013), pp. 73-101.

${ }^{26}$ On the concept of Rechtsschichten, see Babusiaux, 'Coordination of Different Layers of Law', 131-2.

27 Cf. J. Waldon, 'Partly Laws Common to All Mankind': Foreign Law in American Courts (Yale University Press, 2012), pp. 33-5, which makes use of the same Gaius passage in its title: Gaius, Institutes 1.1.1 (The Institutes of Gaius, trans. W. Gordon and O. Robinson (Duckworth, 1988), p. 19).

${ }^{28}$ K. Tuori, 'The Reception of Ancient Legal Thought in Early Modern International Law', in B. Fassbender and A. Peters (eds), The Oxford Handbook of the History of International Law (Oxford University Press, 2012), pp. 1012-33, at pp. 1016-18, citing Cicero, On Duties 3.17.69 and 3.5.23, Tusculan Disputations 1.13.30 and The Divisions of Oratory 37.130; Gaius, Institutes 1.1; Aulus Gellius, Attic Nights 6.3.45; and Justinian Digest, 1.1.1.2, 1.1.4, 1.1.6 (Ulpian). 
Alongside the ius gentium (discussed by some Classical Roman jurists in relation to 'natural law'), Babusiaux identifies three layers of Roman private law: the ius civile narrowly understood (the law of the citizenbody of Rome); the ius praetorium or ius honorarium (the law of the urban praetor - the praetor with jurisdiction between Roman citizens); and 'imperial law' (law enacted by or on behalf of the Roman emperors). ${ }^{29}$ Through a series of detailed case studies, Babusiaux convincingly demonstrates how the application of these different layers of law to specific legal questions could seemingly create clashes, requiring conflicting legal outcomes. The Roman jurist's solution was not to rank the layers of law within an abstract hierarchy of precedence, but rather to reason out their application case by case:

It must therefore be underlined that the Roman jurists were very well aware of the different requirements in the ius civile and ius praetorium, on the one hand, and the imperial law on the other hand. But neither did they coin a general principle in order to overcome these differences nor did they see a general conflict between these requirements. In fact, they seem to stick to a case by case view, in which the different layers had to be harmonised according to the individual circumstances. ${ }^{30}$

The structuring of the different layers of (Roman) law was thus casespecific and dependent on the specialized reasoning techniques of the jurists themselves. In one sense, then, these Roman layers of law can be said to have operated heterarchically: side by side without the presumptive authority of one over the other. Yet the crucial point here is that it was the Roman jurists, the expert legal actors, who provided the overall structure by reasoning out potential overlaps, entanglements and clashes casuistically. ${ }^{31}$

As I argue in Section 13.2, 'postnational' law's focus on legal norms and principles is itself influenced by a modern (Western) tradition: a tradition that links normative-conceptual approaches to 'defining what law is' with territorial approaches to defining nation state sovereignty. ${ }^{32}$ Rather than locating multiplicity and plurality in different bodies of

${ }^{29}$ Babusiaux, 'Coordination of Different Layers of Law', 132-43.

30 Ibid., 142-3.

31 Babusiaux, ibid., suggests that the relevant Roman juristic techniques were developed from Roman rhetorical theory and practice. The article goes on to suggest the potential of applying a similar approach to the 'coordination of different layers of law' within the European Union.

32 See further M. Madero, 'Penser la tradition juridique occidentale' (2012) 67(1) Annales. Histoire, Sciences Sociales 103-32, at 109-10 on the 'fundamental link between the 
overlapping and entangled norms and then positing 'a set of new types of norms at the interfaces between different legal sub-orders', Babusiaux's analysis suggests that we should look to legal actors - in this case the Roman jurists - as structuring agents in their own right. As I suggest in Section 13.3 through a case study of the record of a protracted sixthcentury CE dispute, this focus on legal actors as structuring agents is not simply a question of how different individuals and groups apply legal norms and principles in different times, places and contexts. Rather than adopting a modern 'law in action' or 'law in practice' perspective, Section 13.3 aims to develop an approach to norms and legal actors that is more akin to Lévi-Strauss' disentanglements of Amerindian myths: 'We thus do not pretend to show how men think in myths, but how myths are thought in men, and without their knowledge. ${ }^{33}$

\subsection{Beyond 'Norms' and the Nation State}

As the territorial argument ceases to be the decisive factor for the frontiers of legal orders, a picture unfolds in which the normative-conceptual dimension becomes increasingly important in defining what law is. ${ }^{34}$

From the later twentieth century onwards, jurisprudential attempts to define 'what law is' have become increasingly concerned with the normative-conceptual boundaries of legal 'systems', as opposed to the territorial boundaries of sovereign (nation) states. ${ }^{35}$ As Michael Guidice stated in his 'think piece' for the Geneva 2019 meeting, with reference to H. L. A. Hart, Hans Kelsen and Joseph Raz: 'The concept of a legal system makes it possible to conceive of the membership of all norms within some domain.' Defining a legal system primarily in terms of the norms that it 'contains', in turn, enables the idea of 'norm interaction' across all levels of ordering. Defining the boundaries of legal systems in terms of norms and rules thus opens up space to identify pluralist legal orderings, operating within and beyond the 'conventional, and

political stakes of theories of the state and the role of law in the Western political tradition'.

${ }^{33}$ Lévi-Strauss, Mythologiques, p. 20: 'Nous ne prétendons donc pas montrer comment les hommes pensant dans les mythes, mais comment les mythes se pensent dans les hommes, et à leur insu.'

34 D. Roth-Isigkeit, The Plurality Trilemma: A Geometry of Global Legal Thought (Springer International Publishing, 2018), p. 66.

35 Walker, 'Beyond Boundary Disputes and Basic Grids', especially 373. 
conventionally separate, structures of constitutional law (considered as the law of the Keynesian-Westphalian state) and international law (considered as the law between Keynesian-Westphalian states) ${ }^{36}{ }^{36}$ According to Nico Krisch, "The resulting "postnational law" is thus a frame comprised of different orders and their norms. ${ }^{37}$ Norms which, as we saw in Section 13.1, exist in heterarchical - rather than hierarchical - relation to each other. Hence one of the central claims of Krisch's 'postnational law' paradigm: 'that global law fares better if it embraces plurality, rather than trying to tame it in an institutional model' ${ }^{38}$

To a historian whose research interests lie mainly within the presovereigntist, prenationalist and prepositivist world, the centrality of norms within 'postnational law' and the 'Entangled Legalities' project seems striking. Not only is the 'frame' of postnational law made up of orders which in turn are made up of norms, but the mechanism through which norm interaction is seen to take place is defined as a set of new types of norms, operating at the interfaces between different legal suborders. This set of new types of norms includes 'reception norms': 'the typical form through which a legal system deals with norms from the outside; they reproduce the inside/outside distinction and define the ways in which outside norms enter a given body of norms' (also referred to as between systems/conflict-of-law norms); 'overarching norms' which 'regulate relations centrally and with binding character for the different bodies of norms involved' (also referred to as within system/intra-systemic norms); and 'connecting norms' and 'straddling pactices', the 'norms and practices that straddle different bodies of norms without being seen to belong to either, thus blurring the boundaries between them' ('straddling boundaries'). ${ }^{39}$ Norms have a 'travelling content' through which they perform their operations, becoming entangled within a broader discursive context:

Actors - litigants, judges, dispute settlers, observers, addressees - make claims about the relation of norms from different backgrounds, and they thus define and redefine the relative weights and interconnection between the norms at play. They also define the extent to which norms are perceived to form part of broader assemblages - in the relatively stable and firm mode of modern state legal orders, or in more porous ways, with a more open interplay of norms and characterized more through their

36 Walker, 'Beyond Boundary Disputes and Basic Grids', 374.

37 Krisch, Beyond Constitutionalism, p. 12 (my emphasis).

38 Roth-Isigkeit, The Plurality Trilemma, p. 158.

39 Chapter 1, Section 1.5.1. 
linkages across boundaries than any strong form of belonging to an order as such [...] When we focus on legal entanglement here, we mean such discursive entanglement: the universe of statements that link different bodies of norms with one another. This is similar to the 'relational' (as opposed to 'material') entanglement in cultural studies: an entanglement in which the difference in origin remains visible even if the object is embedded in a different practice. ${ }^{40}$

The explicit focus here is on postnational governance structures and dispute resolution; nonetheless, using norms (and rules) as the primary tools for identifying and framing legal systems is very much part of a modern, 'Keynesian-Westphalian', state-sovereigntist, framework. As Roth-Isigkeit states: 'the legitimacy of norm creation seems one of the most important achievements of the national state'. ${ }^{41}$ What might appear (to 'us') as natural and timeless features of 'strong' legal norms and rules - their binding quality, their normativity, their legitimacy - have in fact been created through modern processes of nation state formation. With its main focus on legal norms - even entangled ones - the 'Entangled Legalities' project does not move us much beyond the (national) state. The fact that the project also includes some analysis of 'weaker' ('informal, unenforced') entangled norms, however, does potentially open up the field to much broader, legal pluralist, perspectives.

The idea that 'strong' legal norms have a jurisdictional aspect is central to both the state-sovereigntist and the postnational-pluralist 'normativisation' (Durchnormierung) of law:

In addition, all rules have a jurisdictional aspect, or an aspect of distribution of power. This is an aspect of legal rules that is sometime overlooked. A legal rule, as we use the term here, attaches consequences to facts. But consequences do not attach to conduct by themselves; someone must manipulate the strings. Each rule, to be a meaningful rule, must carry with it a ticket to some person, agency, or institution, authorizing, permitting, forbidding, or allowing some action to take place. Each rule has its institutional and distributive side as well as its formal and substantive side. It distributes, or redistributes, power within the legal system or within the social order. ${ }^{42}$

The modern (Western) idea that every legal rule carries with it a 'ticket' to institutionalized enforcement links back to the presumption, discussed

40 Chapter 1, Section 1.2.

${ }^{41}$ Roth-Isigkeit, The Plurality Trilemma, p. 60 (my emphasis).

42 L. M. Friedman, 'Legal Rules and the Process of Social Change' (1967) 19 Stanford Law Review $786-840$, at 788. 
in Section 13.1, that law is only meaningful when backed by state power or - to phrase it more loosely - when structured by a LéviStraussian 'Rome'.

'Law in action' and 'law in practice' approaches tend to rely on this modern, Western, idea of legal norms and rules carrying a jurisprudential aspect. It is inherent, for example, in Neil MacCormick's call for a 'userorientated understanding of norms' and also in the wider context of his definition of law itself as an 'institutional normative order. ${ }^{43}$ It is implied in Lon Fuller's 'interaction theory of law' which ascribes an active role to individuals within the 'legal system' through an analysis of their 'interactional expectancies' when engaging with 'enacted law' (i.e. law that is accompanied by an explicit ticket to institutionalized enforcement). ${ }^{44}$ In terms of the international legal sphere, the 'Transnational Legal Process model' relies on norms having a jurisdictional aspect, enabling it to move beyond a formalist concept of rules, in order to stress the role of 'internalized obedience' in developing 'sets of normative practices'. ${ }^{45}$ Finally, the 'Entangled Legalities' project's account of 'norm entanglement' - I would suggest - also relies on the idea of 'strong' legal norms from different origins carrying different jurisdictional 'tickets'. It is precisely this jurisdictional aspect which prevents individual norms from becoming integrated - rather than entangled - through the (repeated, dynamic) 'social interplay of actors':

Norms from different origins become relevant in the same situation, and they often come with divergent prescriptions or at least orientations. Their relations are not predefined but remain to be determined through the social interplay of actors. A common state of affairs in the law - and likely a more common one than legal 'systems' with aspirations of hierarchy, order and coherence, as depicted in the standard image of law in the context of the modern, Western nation state.

Nonetheless, the claim that norm entanglement is 'a common state of affairs in the law' downplays the fact that the 'normativisation' of law is itself the product of a Keynesian-Westphalian, state-sovereigntist,

${ }^{43}$ N. MacCormick, Institutions of Law: Essay in Legal Theory (Oxford University Press, 2007), p. 287.

44 S. Taekema, 'The Many Uses of Law: Interactional Law as a Bridge between Instrumentalism and Law's Values', in N. Roughan and A. Halpin (eds), In Pursuit of Pluralist Jurisprudence (Cambridge University Press, 2017), pp. 116-35, at p. 121.

45 Roth-Isigkeit, The Plurality Trilemma, p. 181. 
'political' framework. ${ }^{46}$ Classical Roman jurists did not understand law (or legal order) as a system of binding, imperative norms. As the Roman legal historian José Luis Alonso Rodriguez states: 'Legal positivism not only means identifying law with legislation tout court [...] It means also the thorough normativisation ("Durchnormierung") of the law, the construction of the entire legal system as a system of imperative, binding norms. Nothing can be more remote from the Roman legal experience in the late Republic and early Empire. ${ }^{, 47}$

We saw in Section 13.1 that relations between the different layers of Roman law were dynamic and heterarchical: they depended on the skill of Roman jurists to reason out potential overlaps, entanglements and clashes on a case-by-case basis. Alonso Rodriguez continues: 'Legal Positivism [...] stems from the normative monopoly of the sovereign and the subjection of the jurisdiction to the law, as theorized in modern political thinking from Hobbes onwards. Such normative monopoly and jurisdictional subjection are alien to the Roman political theory and practice of the late Republic and early Empire. ${ }^{48}$ In other words, Roman legal norms, rules and principles did not carry with them an automatic jurisprudential aspect: 'a ticket to some person, agency, or institution'. Roman jurisdiction was not subjected to the law, but was accorded to specific individuals and groups. These individuals and groups ranged from the formal iurisdictio cum imperio of Roman magistrates and provincial governors, to the legal authority granted to arbitrators by contractual Roman arbitration agreements, to the auctoritas exercised by jurists on account of their technical expertise, to the authority of a Christian bishop, a freelancing 'holy man', an Arab tribal leader, or any other local 'big man', recognized by two parties jointly seeking a (negotiated, mediated or adjudicated) resolution to a dispute.

Legal norms, then, did not define a Roman legal system any more than they defined a Late Antique Talmudic or early Christian legal order. My argument in Section 13.3 is not that legal norms, rules and principles were irrelevant to entangled legalities in Late Antiquity. Rather, I am suggesting that if we place the emphasis on Roman legal norms, we risk

${ }^{46}$ Chapter 1, Section 1.1. On the Keynesian-Westphalian frame as an 'at root [...] political settlement' see Walker, 'Beyond Boundary Disputes and Basic Grids', 393.

${ }^{47}$ J. L. Alonso Rodriguez, 'Customary Law and Legal Pluralism in the Roman Empire: The Status of Peregrine Law in Egypt' (2013) 43 The Journal of Juristic Papyrology 351-404, at 391.

48 Ibid., 391. 
importing a modern jurisprudential aspect to them; and this would be at the expense of neglecting the plurality of entangled legalities that operated, in practice, through concrete appeals to multiple, different, types of power. Section 13.3 thus emphasizes the construction of legalities plural - on the ground and, more specifically, the juris(dictional)generative practices revealed in one sixth-century $\mathrm{CE}$ document: $P$. Petra IV.39, a report of proceedings before arbitrators from the Eastern (Byzantine) Roman Empire. ${ }^{49}$

\subsection{Entangled Legalities: Beyond the (Byzantine) State}

Where actors understand law as a web rather than a hierarchical system, we can expect them to turn away from the ambition of principled solutions - valid throughout the system - and shift towards forms of practical, localized and perhaps provisional accommodation. ${ }^{50}$

There is a history of Late Antique entangled legalities and juris(dictional)-generative practices yet to be written in which what went on in late Roman provinces is not simply labelled 'provincial law' or 'provincial practice' and seen to exist in a hierarchical relationship with laws and practices laid down by the imperial centre, but is instead conceptualized as a kind of heterarchical ordering in its own right. Most legal historians working today on the early Roman Empire (before $212 \mathrm{CE}$ ) would accept that its legal order was pluralistic: that there were multiple normative orders in operation on the ground, some of which were permitted, even encouraged, by the Roman state and some of which operated beyond it. ${ }^{51}$ Whether this kind of legal pluralism persisted much beyond $212 \mathrm{CE}-$ the date of the Emperor Caracalla's grant of Roman citizenship to almost all (free) inhabitants of the Roman Empire - is more fiercely contested. ${ }^{52}$ For our purposes, however, the interesting question is not whether legal

49 P. Petra IV.39 - see M. Kaimio (ed. and trans.), 'Settlement of a Dispute by Arbitration', in A. Arjava, M. Buchholz, T. Gagos and M. Kaimio (eds), The Petra Papyri IV (American Centre of Oriental Research, 2011), pp. 41-120.

${ }^{50}$ See Chapter 1, Section 1.6.2.

${ }^{51}$ K. Tuori, 'Legal Pluralism and the Roman Empire', in J. W. Cairns and P. J. du Plessis (eds), Beyond Dogmatics: Law and Society in the Roman World (Edinburgh University Press, 2007), pp. 39-52; and C. Ando, 'Legal Pluralism in Practice', in P. J. du Plessis, C. Ando and K. Tuori (eds), The Oxford Handbook of Roman Law and Society (Oxford University Press, 2016), pp. 283-93.

52 C. Humfress, 'Laws' Empire: Roman Universalism and Legal Practice', in P. J. du Plessis (ed.), New Frontiers: Law and Society in the Roman World (Edinburgh University Press, 2013), pp. 73-101; and G. Kantor, 'Local Law in Asia Minor after the Constitutio 
pluralism existed within the Roman Empire between the fourth and early seventh centuries - it did - but rather what kinds of legal plurality and hybridity we are talking about. ${ }^{53}$ There is no reference in P. Petra IV.39 to formal Roman court proceedings or imperial bureaucratic legal officials. ${ }^{54}$ Instead, the legal actors mentioned in the document seem to have understood justice-seeking as an interconnected web of possibilities - making use of practical, localized and provisional (at least when viewed from beyond the relevant immediate time frame) - accommodations. As we shall see in the case of the multiple dispute settlements recorded in P. Petra IV.39, Late Antique legal entanglements could stretch across jurisdictional, religious and ethnic boundaries. Through an analysis of P. Petra IV.39 we thus move from pluralism 'as a way an observer might see things from without - to pluralities: to seeing the world as experienced by those who inhabited it'. ${ }^{55}$

Since the 1950s, a wealth of new sixth- and early seventh-century documentary evidence has opened up the field of Late Antique juristic papyrology - the study of law through mainly documentary evidence recorded on papyri - beyond the large mass of texts recovered from Egypt. ${ }^{56}$ The American Center of Oriental Research in Amman, Jordan, has recently coordinated the publication of a remarkable five-volume set of papyri from sixth-century Petra, the remotely located metropolis of

Antoniniana', in C. Ando (ed.), Citizenship and Empire in Europe 200-1900 (Franz Steiner Verlag, 2016), pp. 45-62.

${ }^{53}$ On legal pluralism in the Late Roman East, see Y. Monnickendam, 'Late Antique Christian Law in the Eastern Roman Empire: Toward a New Paradigm' (2018) 2 Studies in Late Antiquity 40-83; on later, post-Islamic conquest legal entanglements, see U. Simonsohn, A Common Justice: The Legal Allegiances of Christians and Jews under Early Islam (University of Pennsylvania, 2011); and M. Tillier (ed.), 'Le Pluralisme judiciaire dans l'Islam prémoderne' (2014) special issue of the Bulletin d'Études Orientales 63.

${ }^{54}$ M. Wojtczak, 'Legal Aspects of Dispute Resolution in Late Antiquity: The Case of $P$. Mich. XIII 659' (2016) 46 The Journal of Juristic Papyrology 275-308, at 307, discusses two Late Antique papyri which explicitly state why disputes were settled 'privately': the distress connected with the court proceedings, the danger of losing a case in public proceedings and the costs of the trial, in particular the judges' fees.

55 Phrase adapted from P. D. Halliday, 'Laws' Histories', in L. Benton and R. J. Ross (eds), Legal Pluralism and Empires 1500-1850 (New York University Press, 2013), pp. 261-77, at p. 273.

56 J. L. Alonso Rodriguez, 'Juristic Papyrology and Roman Law', in P. J. du Plessis, C. Ando and K. Tuori (eds), The Oxford Handbook of Roman Law and Society (Oxford University Press, 2016), pp. 56-66. 
the Roman border province Palaestina Tertia. ${ }^{57}$ The papyri were found in December 1993, as part of ongoing excavations of the Byzantine Church of the Virgin Mary in Petra led by the American Center of Oriental Research. Two teams of papyrologists - an American team from Michigan University and a Finnish team from Helsinki - worked with around 140 carbonized rolls, reconstructing the private papers of a certain Theodoros, son of Obodianos (born $514 \mathrm{CE}$ and died $591 \mathrm{CE}$ ), a property owner, deacon and later archdeacon of the Christian Church of the Virgin Mary in Petra (the location where the papyrus rolls were found). ${ }^{58}$ Taken as a whole, the Petra archive provides evidence for the persistence of Roman forms and structures in the city of Petra and its surrounding localities: there was a continued Roman military presence and the centralized land-tax system of the Byzantine Empire was still being implemented up to at least the period of the Arab conquests (c.634-8 CE). ${ }^{59}$ Yet when read together with Late Antique papyri from Egypt, in addition to other papyri from the Near East, the Petra archive does not reveal an Eastern Provincial law: 'a hybrid, indigenous law of the Near East'. ${ }^{60}$ Instead, we see a series of concrete situations in which individuals and groups around and beyond the Late Antique eastern Mediterranean - Syria, Palestine, the Arabian Peninsula and Egypt made use of numerous, entangled, legal practices, forms of argument and juris(dictional)-generative situations in order to get things done.

P. Petra IV.39 is a complex and incomplete text, reconstructed from around 3,000 fragments of papyri by its editor Maarit Kaimio and others. The document is a report of proceedings before arbitrators (dikastai), probably drawn up on 8 August $574 \mathrm{CE}$ by an official notary from the Kastron Zadakathon (Sadaqa), a garrisoned, fortified settlement $20 \mathrm{~km}$ south of Petra on the margins of the Eastern Roman Empire. The reconstituted papyrus' extant length is a remarkable c.6.2-6.5 metres,

${ }^{57}$ J. Frösen, A. Arjava and M. Lehtinen (eds), The Petra Papyri I (American Centre of Oriental Research, 2002); L. Koenen, J. Kaimio, M. Kaimio and R. W. Daniel (eds), The Petra Papyri II (American Centre of Oriental Research, 2013); A. Arjava, M. Buchholz and T. Gagos (eds), The Petra Papyri III (American Centre of Oriental Research, 2007); Arjava et al., Petra Papyri IV; and A. Arjava, J. Frösén and J. Kaimio (eds), The Petra Papyri V (American Centre of Oriental Research, 2018).

${ }^{58}$ L. Koenen, 'The Decipherment and Edition of the Petra Papyri: Preliminary Observations', in L. H. Schiffman (ed.), Semitic Papyrology in Context: A Climate of Creativity (Brill, 2003), pp. 201-26, at p. 202.

59 See ibid., p. 212, on the centralised land-tax system in operation at Petra.

60 P. Crone, Roman, Provincial, and Islamic Law (Cambridge University Press, 1987), p. 99. 
with 523 lines of text surviving. Nine different hands can be distinguished in the document, with one clear cursive hand indicating a trained scribe. ${ }^{61}$ The document itself is written in Greek, but its contents reveal a multilingual environment. At certain points the papyrus refers to two languages being used simultaneously: Greek and 'Syriac' (probably an Aramaic dialect). ${ }^{62}$ Both of the parties involved in the 574 CE dispute Theodoros, son of Obodianos, and Stephanos, son of Leontius - are clergymen; as is Heiros, son of Thomallos, who drafted the arbitration agreement's stipulation of penalty, and one of the arbitrators, Theodoros, son of Alpheios who is identified in the document as an archdeacon. The other arbitrator, Flavius Thomas, son of Boethos, was a senior officer in the local military unit garrisoned at Sadaqa. ${ }^{63}$ As discussed in more detail later in this section, the record of the $574 \mathrm{CE}$ arbitration settlement refers to two previously negotiated settlements: one probably from the 530s, decided by an Arab tribal leader and a further settlement from sometime before $574 \mathrm{CE}$ that had been mediated by a Christian cleric from a neighbouring rural area. In addition to arbitration and mediation proceedings, P. Petra IV.39 also refers to other forms of justice-seeking, which include trips to the 'sacred shrine of the holy and glorious martyr Kerykos' (in Sadaqa) in order to swear oaths of innocence on the Christian Holy Scriptures. ${ }^{64}$

The report of proceedings given in P. Petra IV.39 touches upon numerous points of dispute, all related to the fact that Theodoros son of Obodianos and Stephanos son of Leontius owned neighbouring properties in Sadaqa, as had their fathers before them. Theodoros and his father, however, seem to have been absentee property owners; at line 103 in the text Theodoros responds indignantly to an accusation that he does not 'care for local matters'. Stephanos, on the other hand, seems to have taken advantage of Theodoros' absence from Sadaqa in order to build new physical structures and make alterations to the flow of the

${ }^{61}$ Arjava et al., Petra Papyri IV, p. 45.

${ }^{62}$ Arjava et al., Petra Papyri IV, p. 72, lines 475-85, mentions documents being presented in both Greek and Syriac letters.

${ }^{63}$ Ibid., p. 45. Further discussion in Z. T. Fiema, 'The Byzantine Military in the Petra Papyri: A Summary', in A. Lewin, P. Pellegrini, Z. T. Fiema and S. Janniard (eds), The Late Roman Army in the Near East from Diocletian to the Arab Conquest (Archaeopress, 2007), pp. 313-19.

64 Arjava et al., Petra Papyri IV, pp. 72-3, lines 475-85 and 485-95. 
water supply without Theodoros' approval. ${ }^{65}$ This led to disputes over Stephanos' and Theodoros' rights to the water that drained from a roofspout, which had originally been constructed by Theodoros and was the subject of an earlier dispute mediated by the 'country bishop' Sergios. ${ }^{66}$ Who owned which parts of the adjacent properties was also at issue, including rights of access across a central courtyard and rights of ownership relating to a refuse pit and an outbuilding. ${ }^{67}$ Theodoros claimed that the outbuilding was his by right of inheritance, producing a written deed of sale made for his father seventy years ago. ${ }^{68} \mathrm{He}$ also seems to claim that he had been sold the outbuilding by two other individuals (Kassisaios and Gregoria), but could not produce any supporting written documents. Stephanos, meanwhile, counter-claimed that his father had bought the outbuilding and surrounding courtyard fifty-three years ago, apparently from Theodoros' father. Stephanos produced two deeds of sale, but Theodoros responded that the outbuilding and surrounding land had not been included in the transaction. Added to this complex situation, P. Petra IV.39 also includes accusations of encroachment and theft of building materials - timber, blocks of stone and doors - by local soldiers, possibly under the command of one of the $574 \mathrm{CE}$ arbitrators: Flavius Thomas. ${ }^{69}$ In addition, the document records a further, rather murky, claim for two solidi (gold coins) related to an earlier dispute between the families over a vineyard. ${ }^{70}$ Perhaps unsurprisingly, the hostilities between the two families spilled out into the local community, with Stephanos accusing Theodoros of deliberately stirring things up with the neighbours - who, we are told, made many 'unwritten accusations..$^{71}$ P. Petra IV.39 thus records a longstanding series of disputes between two local families, spanning several decades. There is obviously a complex backstory to the $574 \mathrm{CE}$ arbitration. As a 546/7 CE papyrus from the Egyptian city of Antinoe put it, 'many words

65 Ibid., p. 51, and M. Wojczak, 'Settlements of Claims as a Way of Dispute Resolution in the Light of P. Petra IV 39: A Legal Commentary' (2012) 42 The Journal of Juristic Papyrology 353-80 at 359.

66 Arjava et al., Petra Papyri IV, p. 54.

67 Ibid., p. 53. The refuse pit, in particular, seems to have been the object of a longstanding feud.

68 Ibid., pp. 52 and 69, lines 69-79.

69 Arjava et al., Petra Papyri IV, p. 55.

70 Ibid., p. 55.

71 Ibid., p. 71, lines 305-19. 
have been said and many moves have been made' before the parties brought their case before the arbitrators. ${ }^{72}$

Arbitration (and mediation), in contrast to judicial settlement by a standing tribunal, is designed by the parties to the dispute. The basic modern 'principle of party autonomy' - that the parties agree which issue(s) to submit to arbitration, that is, the issues to be decided upon; the choice of arbitrator(s); and the 'applicable law', that is, the law applicable to the dispute, including soft law and 'non-binding' law - can also be seen in operation in Roman arbitration proceedings. Similarly, the modern distinction between 'ad hoc arbitration' and 'institutional arbitration' (where the parties rely on the procedural rules of an arbitral institution determined by the relevant institution) can also be seen in Late Antique contexts. Arbitrations and other negotiation settlements before Late Antique Christian bishops and clerics, for example, developed institutionally specific norms and practices. Records of proceedings held before arbitrators and formal arbitration agreements survive on papyri from both the Late Antique Near East and the West. These include an Egyptian record of a dispute settled by arbitration in $647 \mathrm{CE}$ and recorded in Coptic, which the editor of P. Petra IV.39, Maarit Kaimio, notes as the closest parallel to our $574 \mathrm{CE}$ text. P. Petra IV.39, however, is unique in that it refers to the submission of written pleas and documents at an early stage of the proceedings, but records the parties' oral pleas before the arbitrators in direct speech: 'the speech flows in personal style, often becoming agitated and even insulting. ${ }^{73}$ In other words, aside from the opening and concluding formalities of the arbitration procedure and the stipulation of penalty, the language used by the parties is not formulaic. What we see recorded in P. Petra IV.39 is a localized culture of argumentation.

Chronologically, the earliest negotiated settlement mentioned in P. Petra IV.39 relates to the vineyard and the claim for two solidi. This dispute, the papyrus states, occurred sometime in the past - Kaimio suggests the late 520 s or 530 s - between Theodoros, son of Obodianos and Leontius, the father of Stephanos. It was resolved before a mediator referred to in the document as 'Abou Cherebos'. This is probably Abu Karib ibn Jabala, part of the Jafnid dynasty that acted as power brokers between Rome and the Bedouin. ${ }^{74}$ Abu Karib ibn Jabala was granted the

72 Wojtczak, 'Legal Aspects of Dispute Resolution', 36.

73 Arjava et al., Petra Papyri IV, p. 48.

74 Ibid., pp. 55 and 90 (commenting on lines $163-87$ of the text). 
Phylarcate of Palestine (including southern Jordan and Petra) by the Roman Emperor Justinian sometime in the 530s. ${ }^{75}$ Thus we have a relatively minor dispute over a vineyard, involving two landowners of middling means, mediated by an Arab tribal leader with a network of contacts that stretched all the way from (present-day) Jordan to the Emperor in Constantinople. ${ }^{76}$ In choosing Abu Karib as the mediator of their dispute, Theodoros and Leontius deliberately exploited local and imperial networks. The second negotiated settlement mentioned in $P$. Petra IV.39 took place sometime before 574 and was concluded between Theodoros, son of Obodianos, and the individual whom he claimed to have bought the disputed outbuilding from: a certain Kassisaios. The memorandum of this agreement, included in the documents submitted to the $574 \mathrm{CE}$ arbitrators, states that it was made through 'Sergios, priest and "country-bishop" (chorepiscopos). ${ }^{77}$ Here we have the parties appealing to a Christian cleric from a neighbouring rural area, perhaps either exploiting a personal network or, conversely, attempting to remove the dispute from its immediate, urban, context. We also see the use of a Christian cleric as arbitrator in the 574 CE settlement itself, alongside a high-ranking military officer who may have been directly implicated in the circumstances of the case. P. Petra IV.39 thus presents us with multiple justice-seeking attempts, before multiple individuals of different types. The crucial point to note here is that each of the different venues for dispute resolution were put into relation with each other by the parties to the disputes themselves. The interlinkage here is literally created through the parties' own juris(dictional)-generative practices.

We turn, finally, to the legal norms and principles that the parties rely upon in their justice-seeking activities. In common with other papyri in the Petra and Nessana archives, the protocol of P. Petra IV.39 seems to make use of procedural terms and concepts derived from Roman

75 Procopius, History of the Wars I.xix.10-13, states that Justinian received a gift of 'the palmtrees' from Abu Karim, 'who now guarded the land from plunder'. In a brilliant example of Late Antique realpolitik, however, Procopius goes on to explain that, 'In formal terms the emperor holds the Palmtrees, but for him [Justinian] to possess himself of any of the country is in practice utterly impossible [...] The Palmtrees themselves are worth nothing and Abocharabos [Abu Karib ibn Jabala] only gave the form of a gift, and the emperor accepted it with full knowledge of the fact.'

76 E. K. Fowden, The Barbarian Plain: Saint Sergius between Rome and Iran (University of California Press, 1999), pp. 167-70, notes that the Jafnid family constructed an 'audience hall' south of the town of Resafa which functioned as a Church and a place for dispute settlement for people coming on pilgrimage to the shrine of St Sergius.

77 Arjava et al., Petra Papyri IV, pp. 50, 54 and 69. 
law: 'Instances of such terms in the text demonstrate beyond doubt that the parties and arbitrators had some, considerable, specific legal knowledge. ${ }^{, 78}$ Marzena Wojtczak's careful and cautious reconstruction of the substantive Roman rules and concepts that can be pieced together from P. Petra IV.39 also suggests the use of legal norms and concepts derived from Roman law, while at the same time highlighting the specificity of localized practices. ${ }^{79}$ According to Wojtczak, P. Petra IV.39 'gives an impression that we are actually dealing with a sequence of debts and securities between the two families', involving 'a sequence of fiduciary or fictitious sales' with multiple ownership changes over a relatively short period of time (what a modern lawyer might refer to as a situation of relational contracting). ${ }^{80}$ As Wojtczak's article concludes: 'It should be considered that ordinary people, not acquainted with dogmatic legal patterns, sought solutions which would appear to protect their rights in [the] best possible manner. Transfer of ownership treated as a security for credit seems to be in accord with this idea. ${ }^{, 81}$

The use of a technical Roman legal register in P. Petra IV.39 thus needs to be understood within the context of local relations and localized practices. Evidence for these localized practices can be difficult to pinpoint in Late Antique legal and documentary source material, nonetheless, as Wojtczak's example of the creative, 'localized' use of multiple fiduciary or fictitious sales suggests, Roman legal concepts and practices were put to work differently, by different networks of individuals, families and groups, operating within different localities around the empire. Moreover, the fact that this creative use of Roman legal norms in P. Petra IV.39 is apparent across a succession of settlements, decided in turn by Christian clerics, a Roman military official and an Arab tribal leader, underscores the fact that the Roman legal norms themselves were considered 'portable'. Once again, there may be modern parallels to be teased out here in terms of exploring the relationship between entangled legalities on the ground and 'strategic legal argumentation'. For example, Adam Bower stresses the role played by 'strategic legal argumentation' in contemporary multilateral settings: 'First, in multilateral settings actors will tend to invoke justifications based in legal principles, norms, and rules - potentially in conjunction with coercive efforts - in pursuing

\footnotetext{
78 Wojtczak, 'Settlements of Claims as a Way of Dispute Resolution', 357-8.

79 Ibid., 360-80.

80 Ibid., 377-9.

81 Ibid., 379-80.
} 
policy goals. This strategy is preferable even when the actor making a claim does not fully endorse the standards it employs. ${ }^{, 82}$ Strategic legal argumentation, I would suggest, is at least as important as ('travelling') legal norms when it comes to the construction of entangled legalities past and present.

While it may be tempting to interpret P. Petra IV.39, and the Petra archive more generally, as evidence for the persistence of Roman forms and structures (the Roman military, the Roman land ownership and taxation system, Roman legal norms and principles), this would risk sidelining the situated, entangled web of practices that I discuss in this chapter. The fact that Roman legal norms underpin some of the parties' direct speech as recorded in P. Petra IV.39 is an important point, but Roman law should not be understood as 'the' centralizing, organizing, principle at work across the life of these disputes. What P. Petra IV.39 suggests instead is a complex picture of connected localisms: Roman military networks are enmeshed within civilian, urban, life; Arab tribal leaders mediate property disputes between Christian clerics; and urban clerical networks intersect with wider rural connections. To reduce this connectivity to a static (Roman) provincial law would in fact sideline the extent to which Roman legal norms were put to work, by the parties themselves, in concrete situations and contexts. P. Petra IV.39 shows us sixth-century legal actors operating at the margins of empire, mobilizing multiple networks and regimes - local, regional, trans-regional, imperial and in the process creating connected, but crucially not integrated, legal orderings of their own.

\subsection{Conclusion}

With our analysis of the presovereigntist, prenationalist and prepositivist world of P. Petra IV.39 we have moved far beyond a modern, statesovereigntist, court-centric framework. P. Petra IV.39, in contrast, underscores the central role of legal actors in creating localized and entangled legalities on the ground; entangled legalities within which arguments from - portable - Roman legal norms and principles play a significant, but not determinate, role. One of the central questions posed by the 'Entangled Legalities' project is how to reimagine the global legal order

82 A. Bower, 'Arguing with Law: Strategic Legal Argumentation, US Diplomacy, and Debates over the International Criminal Court' (2015) 41 Review of international Studies 337-60, at 339 . 
through the paradigm of entangled legalities. I would argue that one answer involves reframing the analysis so that it shifts from a predominate concern with legal norms towards a 'user theory of jurisdiction': an analysis of the ways in which different legal actors shape themselves to the jurisdictional claims made by state, non-state and extra-state authorities and, in turn, work to shape the concept of jurisdiction itself. As Nico Krisch states: 'the systemic, hierarchical and exclusive [image of law] may well constitute the exception rather than the rule. ${ }^{83}$

${ }^{83}$ See Chapter 1, Section 1.6.2. 